\title{
Simple, Qualities, Efficient and Secure Method to Encrypt Voice Signal
}

\author{
Mohammad S. Khrisat, PhD \\ Albalqa Applied University, Faculty \\ of engineering Technology, Jordan
}

\author{
Hatim Ghazi Zaini, PhD \\ Taif University, Computer and \\ Information Technology College,
}

\author{
Ziad AlQadi \\ Albalqa Applied University, Faculty \\ of engineering Technology, Jordan
} KSA

\begin{abstract}
Voice signal cryptography is needed process to protect the voice signal from any third party, because the wave file may be confidential or may contain valuable secret information. In tis paper research we will introduce a method of voice signal encryption- decryption base on using a huge RGB color image as secret key, this image cab be easily used to create encryption-decryption private key. It will be shown that the proposed method will be qualities by destroying the original file to generate the encrypting one, and recovering identical to the original decrypted file. The efficiency the proposed method will be calculated to show the productivity of this method.
\end{abstract}

\section{Keywords}

Voice signal, encryption, decryption, MSE, PSNR, throughput, RGB, YIQ, PK.

\section{INTRODUCTION}

Digital voice signal [14], [34] is a 1D matrix (mono speech) or $2 \mathrm{D}$ matrix(stereo speech), each element in the matix represents the amplitude value of the voice sample at a given time( see figure 1), these values usually between -1 and 1 . Voice signals some time require encryption-decryption, beacuase they may contain secret information or may be private, so no other third party must not understand it[36-42].

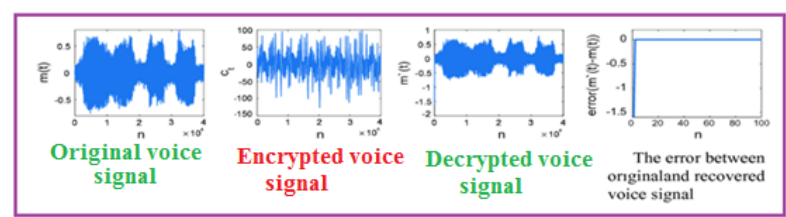

Figure 1: Voice signal encryption-decryprtion

Encryption means fully distruction of the original signal, amking the output of this process un undertandable and useless information, while the decryprtion means recovering from the decrypted signal the original one without lossing any piece of information, the recovered signal must be identical to the original one. Here the encryption-decryption process must have the following qauntitive parameters[15-25]:

Mean square error (MSE) between the original signal and the encrypted one must have a large value.

Peak signal to noise ratio (PSNR) between the original signal and the encrypted one must have a very small value.

- Mean square error (MSE) between the original signal and the decrypted one must be closed to zero.
Peak signal to noise ratio (PSNR) between the original signal and the decrypted one must have a large value.

Symmetic cryptography as shown in figure 2 usual uses a private key known only by the sender and the reciever, this key can be a hige color image, here the sender and reciever must agree on the image and keep it saved to be used as a private $\mathrm{key}(\mathrm{PK})[26-37]$.

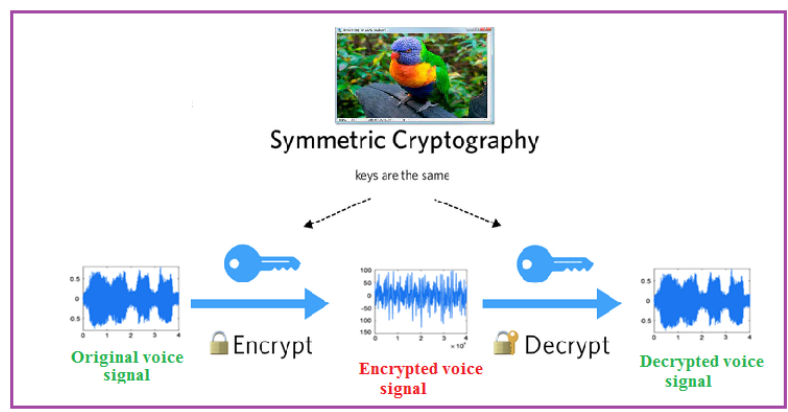

Figure 2: Symmetric cryptography

Digital RGB [1], [2],[3] color image usually represented by a 3D matrix, one 2D matrix for each color (red, green and blue), the value of each pixel is within the range 0 to 255 , to make this image appilicable for voice proceesing we can convert this image to ntsc image with three channels(YIQ), here the range of YIQ image will be between -1 and 1, [4-14] the process of coversion RGB image to YIQ image can be implemented applying equation 1 :

$$
\left[\begin{array}{l}
Y \\
I \\
Q
\end{array}\right]=\left[\begin{array}{rrr}
0.299 & 0.587 & 0.114 \\
0.596 & -0.274 & -0.322 \\
0.211 & -0.523 & 0.312
\end{array}\right]\left[\begin{array}{l}
R \\
G \\
B
\end{array}\right]
$$

\section{THE PROPOSED METHOD}

The proposed method as shown in figure 3 can be implemented applying the following steps:

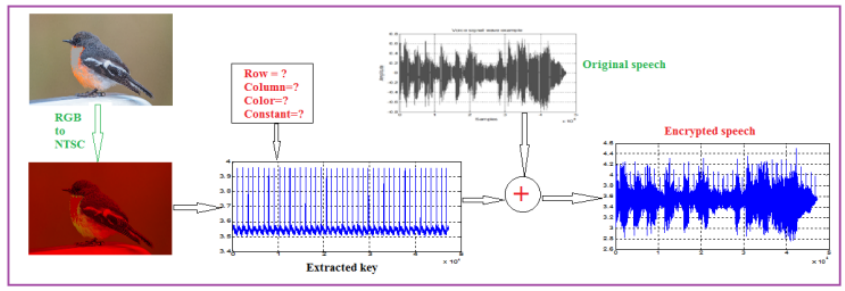

Figure 3: Proposed method diagram 
Encryption phase:

This phase can be implemeneted applying the following steps:

Step 1: Key preparation

Here we have to do the following:

- $\quad$ Select the secret image which is to be used as a secret key.

- $\quad$ Convert the image to YIQ image.

- $\quad$ Select the row, column and color channel, where to start extracting the key.

- $\quad$ Extract the key with length equal voice file length.

- $\quad$ Add the constant to the key.

Step 2: Encryption:

Add the key to the voice file to get the encrypted voice file.

The decryption phase can be implemented applying the following:

Decryption phase:

This phase can be implemeneted applying the following steps:

Step 1: Key preparation

Here we have to do the following:

- $\quad$ Select the secret image which is to be used as a secret key.

- $\quad$ Convert the image to YIQ image.

- Select the row, column and color channel, where to start extracting the key.

- $\quad$ Extract the key with length equal voice file length.

- $\quad$ Add the constant to the key.

Step 2: Decryption:

Subtract the key from the encrypted voice file to get the decrypted voice file.

\section{IMPLEMENTATION AND EXPERIMENTAL RSULTS}

A big RGB color image shown in figure 4 was selected as a secret image to be used to extract the private key, figure 5 shows the YIQ version of the original image:

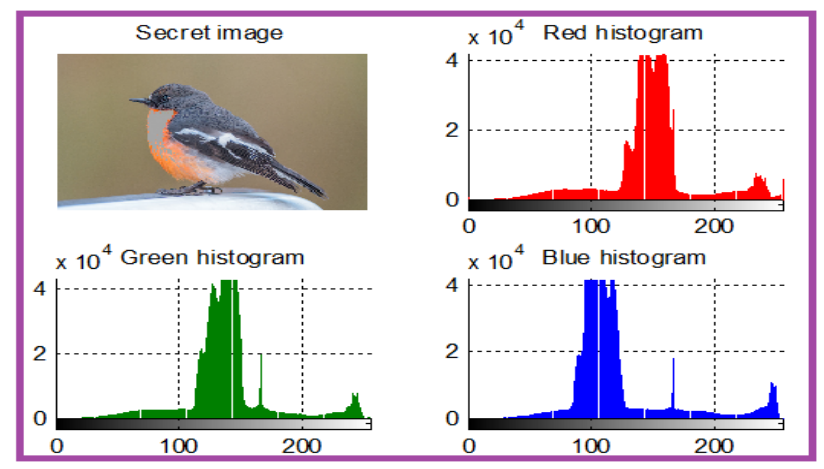

Figure 4: Selected RGB secret image

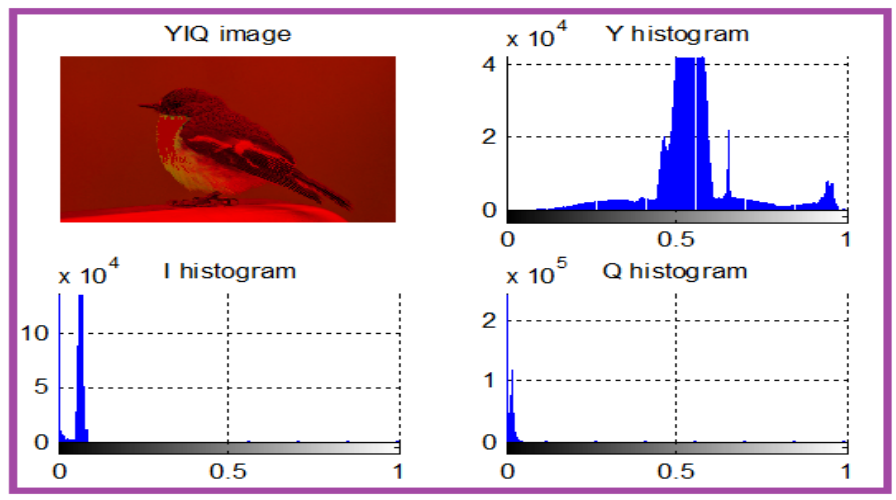

Figure 5: YIQ image

(here we have to notice that it is easy to change the secret image by onther image without adding any changes to the encryption-decryption process).

To test the qualitive parameters of the propossed method( Increasing MSE between the original and the encrypted signals and to decrease MSe between the original and decrypted signals) various voice signal were selected and they were encrypted-decrypted using the secret image shown in figure 4 , table 1 shows the obtained experimental results:

Table 1: Obtained results of qualitive parameters

\begin{tabular}{|l|l|l|l|l|}
\hline \multirow{2}{*}{$\begin{array}{l}\text { Voice } \\
\text { signal } \\
\text { number }\end{array}$} & \multicolumn{2}{|l|}{$\begin{array}{l}\text { Original and } \\
\text { encrypted signals }\end{array}$} & \multicolumn{2}{l|}{$\begin{array}{l}\text { Original and decrypted } \\
\text { signals }\end{array}$} \\
\cline { 2 - 5 } & MSE & PSNR & MSE & PSNR \\
\hline 1 & 12.6121 & 4.7445 & $\begin{array}{l}6.9191 \mathrm{e}- \\
034\end{array}$ & 756.7127 \\
\hline 2 & 12.6390 & 3.0727 & $\begin{array}{l}5.5202 \mathrm{e}- \\
035\end{array}$ & 762.4994 \\
\hline 3 & 12.6356 & 3.2529 & $\begin{array}{l}2.3583 \mathrm{e}- \\
035\end{array}$ & 768.7798 \\
\hline 4 & 12.6374 & 2.9669 & $\begin{array}{l}1.1278 \mathrm{e}- \\
035\end{array}$ & 776.2908 \\
\hline 5 & 12.6398 & 3.3253 & $\begin{array}{l}4.9982 \mathrm{e}- \\
035\end{array}$ & 764.8114 \\
\hline 6 & 12.6324 & 2.5131 & $\begin{array}{l}1.1464 \mathrm{e}- \\
036\end{array}$ & 778.3464 \\
\hline 7 & 12.6270 & 2.3912 & 0 & infinit \\
\hline 8 & 12.6366 & 2.4409 & 0 & infinit \\
\hline 9 & 12.6394 & 2.5242 & $\begin{array}{l}2.1721 \mathrm{e}- \\
036\end{array}$ & 785.9859 \\
\hline 10 & 12.6079 & 3.2120 & $\begin{array}{l}4.5150 \mathrm{e}- \\
035\end{array}$ & 765.9874 \\
\hline & & & & \\
\hline & & & & \\
\hline
\end{tabular}

From table 1 we can see that the proposed method has a good qualitive parameters values, here the method provides a good values for MSE and PSNR in the encryption and decryption phases.

The same voice signals were treated using the proposed method, table 2 shows the effeclency parameters values obtained in this experiment: 
Table 2: Obtained results of effeciency parameters

\begin{tabular}{|c|c|c|c|c|c|}
\hline $\begin{array}{l}\text { Voic } \\
\mathrm{e} \\
\text { signa } \\
1 \\
\text { num } \\
\text { ber }\end{array}$ & $\begin{array}{l}\text { Size } \\
\text { (samp } \\
\text { les) }\end{array}$ & $\begin{array}{l}\text { Size(by } \\
\text { tes) }\end{array}$ & $\begin{array}{l}\text { Encrypti } \\
\text { on } \\
\text { time(sec } \\
\text { onds) }\end{array}$ & $\begin{array}{l}\text { Through } \\
\text { put } \\
\text { (samples } \\
\text { per } \\
\text { second) }\end{array}$ & $\begin{array}{l}\text { Through } \\
\text { put } \\
\text { (bytes } \\
\text { per } \\
\text { second) }\end{array}$ \\
\hline & 47315 & 378520 & 0.1930 & $\begin{array}{l}2.4516 \mathrm{e} \\
+005\end{array}$ & $\begin{array}{l}1.9612 \mathrm{e} \\
+006\end{array}$ \\
\hline 1 & $\begin{array}{l}32153 \\
6\end{array}$ & $\begin{array}{l}257228 \\
8\end{array}$ & 0.4340 & $\begin{array}{l}7.4087 \mathrm{e} \\
+005\end{array}$ & $\begin{array}{l}5.9269 \mathrm{e} \\
+006\end{array}$ \\
\hline 2 & $\begin{array}{l}20070 \\
4\end{array}$ & $\begin{array}{l}160563 \\
2\end{array}$ & 0.1940 & $\begin{array}{l}1.0346 \mathrm{e} \\
+006\end{array}$ & $\begin{array}{l}8.2765 \mathrm{e} \\
+006\end{array}$ \\
\hline 3 & $\begin{array}{l}22732 \\
8\end{array}$ & $\begin{array}{l}181862 \\
4\end{array}$ & 0.1920 & $\begin{array}{l}1.1840 \mathrm{e} \\
+006\end{array}$ & $\begin{array}{l}9.4720 \mathrm{e} \\
+006\end{array}$ \\
\hline 4 & $\begin{array}{l}43008 \\
0\end{array}$ & $\begin{array}{l}344064 \\
0\end{array}$ & 0.1960 & $\begin{array}{l}2.1943 \mathrm{e} \\
+006\end{array}$ & $\begin{array}{l}1.7554 \mathrm{e} \\
+007\end{array}$ \\
\hline 5 & $\begin{array}{l}43008 \\
0\end{array}$ & $\begin{array}{l}344064 \\
0\end{array}$ & 0.2020 & $\begin{array}{l}2.1291 \mathrm{e} \\
+006\end{array}$ & $\begin{array}{l}1.7033 \mathrm{e} \\
+007\end{array}$ \\
\hline 6 & $\begin{array}{l}17203 \\
2\end{array}$ & $\begin{array}{l}137625 \\
6\end{array}$ & 0.2410 & $\begin{array}{l}7.1383 \mathrm{e} \\
+005\end{array}$ & $\begin{array}{l}5.7106 \mathrm{e} \\
+006\end{array}$ \\
\hline 7 & $\begin{array}{l}13312 \\
0\end{array}$ & $\begin{array}{l}106496 \\
0\end{array}$ & 0.1900 & $\begin{array}{l}7.0063 \mathrm{e} \\
+005\end{array}$ & $\begin{array}{l}5.6051 \mathrm{e} \\
+006\end{array}$ \\
\hline 8 & $\begin{array}{l}21299 \\
2\end{array}$ & $\begin{array}{l}170393 \\
6\end{array}$ & 0.1940 & $\begin{array}{l}1.0979 \mathrm{e} \\
+006\end{array}$ & $\begin{array}{l}8.7832 \mathrm{e} \\
+006\end{array}$ \\
\hline 9 & $\begin{array}{l}27238 \\
4\end{array}$ & $\begin{array}{l}217907 \\
2\end{array}$ & 0.1940 & $\begin{array}{l}1.4040 \mathrm{e} \\
+006\end{array}$ & $\begin{array}{l}1.1232 \mathrm{e} \\
+007\end{array}$ \\
\hline 10 & 17472 & 139776 & 0.1910 & $\begin{array}{l}9.1476 \mathrm{e} \\
+004\end{array}$ & $\begin{array}{l}7.3181 \mathrm{e} \\
+005\end{array}$ \\
\hline
\end{tabular}

From table 2 we can see that the proposed method has a good effeciency parameters values, here the method provides a good values for encryption time and the throughput in the encryption and decryption phases.

\section{CONCLUSION}

A simple and easy method of voice signal encryptiondecryption was proposed, the method provides a high level of security by using a changeable secret RGB color image to generate a private key. The method was tested and implemented using various voice signals, the obtained experimental results showed that the proposed methed is higly qualitive and efficient by propviding a good value for the quality and effeciency parameters.

\section{REFERENCES}

[1] Majed O Al-Dwairi, Ziad A Alqadi, Amjad A Abujazar, Rushdi Abu Zneit, Optimized true-color image processing, World Applied Sciences Journal, vol. 8, issue 10, pp. 1175-1182, 2010.

[2] Jamil Al Azzeh, Hussein Alhatamleh, Ziad A Alqadi, Mohammad Khalil Abuzalata, Creating a Color Map to be used to Convert a Gray Image to Color Image, International Journal of Computer Applications, vol. 153, issue 2, pp. 31-34, 2016.

[3] Qazem Jaber Ziad Alqadi, Jamil azza, Statistical analysis of methods used to enhance color image histogram, XX International scientific and technical conference, 2017.

[4] Bassam Subaih Ziad Alqadi, HamdanMazen, A Methodology to Analyze Objects in Digital Image using Matlab, International Journal of Computer Science \& Mobile Computing, vol. 5, issue 11, pp. 21-28, 2016.

[5] Mazen A.Hamdan Bassam M.Subaih, Prof. Ziad A. Alqadi, Extracting Isolated Words from an Image of Text, International Journal of Computer Science \& Mobile Computing, vol. 5, issue 11, pp. 29-36, 2016.

[6] Dr. Amjad Hindi, Dr. Majed Omar Dwairi, Prof. Ziad Alqadi, Analysis of Procedures used to build an Optimal Fingerprint Recognition System, International Journal of Computer Science and Mobile Computing, vol. 9, issue 2, pp. $21-37,2020$.

[7] Aws AlQaisi, Mokhled AlTarawneh, Ziad A. Alqadi, Ahmad A. Sharadqah, Analysis of Color Image Features Extraction using Texture Methods, TELKOMNIKA, vol. 17, issue 3, pp. 1220-1225, 2019.

[8] Ahmad Sharadqh Naseem Asad, Ismail Shayeb, Qazem Jaber, Belal Ayyoub, Ziad Alqadi, Creating a Stable and Fixed Features Array for Digital Color Image, IJCSMC, vol. 8, issue 8, pp. 50-56, 2019.

[9] Ziad Alqadi, Dr. Mohammad S. Khrisat, Dr. Amjad Hindi, Dr. Majed Omar Dwairi, VALUABLE WAVELET PACKET INFORMATION TO ANALYZE COLOR IMAGES FEATURES, International Journal of Current Advanced Research, vol. 9, issue 2, pp. 2319,2020.

[10] Ziad AlQadi, M Elsayyed Hussein, Window Averaging Method to Create a Feature Victor for RGB Color Image, International Journal of Computer Science and Mobile Computing, vol. 6, issue 2, pp. 60-66, 2017.

[11] Bilal Zahran Belal Ayyoub, Jihad Nader, Ziad Al-Qadi, Suggested Method to Create Color Image Features Victor, Journal of Engineering and Applied Sciences, vol. 14, issue 1, pp. 2203-2207, 2019.

[12] Ahmad Sharadqh Naseem Asad, Ismail Shayeb, Qazem Jaber, Belal Ayyoub, Ziad Alqadi, Creating a Stable and Fixed Features Array for Digital Color Image, IJCSMC, vol. 8, issue 8, pp. 50-56, 2019.

[13] Yousf Eltous Ziad A. AlQadi, Ghazi M. Qaryouti, Mohammad Abuzalata, ANALYSIS OF DIGITAL SIGNAL FEATURES EXTRACTION BASED ON KMEANS CLUSTERING, International Journal of Engineering Technology Research \& Management, vol. 4, issue 1, pp. 66-75, 2020.

[14] Ziad A AlQadi Amjad Y Hindi, O Dwairi Majed, PROCEDURES FOR SPEECH RECOGNITION USING LPC AND ANN, International Journal of Engineering Technology Research \& Management, vol. 4, issue 2, pp. 48-55, 2020.

[15] Majed O. Al-Dwairi, Amjad Y. Hendi, Mohamed S. Soliman, Ziad A.A. Alqadi, A new method for voice signal features creation, International Journal of 
Electrical and Computer Engineering (IJECE), vol. 9, issue 5, pp. 4092-4098, 2019.

[16] Ziad Alqadi, Majid Oraiqat, Hisham Almujafet, Salah Al-Saleh, Hind Al Husban, Soubhi Al-Rimawi, A New Approach for Data Cryptography, International Journal of Computer Science and Mobile Computing, vol. 8, issue 8, pp. 30-48, 2019.

[17] Ayman Al-Rawashdeh, Ziad Al-Qadi, Using wave equation to extract digital signal features, Engineering, Technology \& Applied Science Research, vol. 8, issue 4, pp. 1356-1359, 2018.

[18] Aws Al-Qaisi, Saleh A Khawatreh, Ahmad A Sharadqah, Ziad A Alqadi, Wave File Features Extraction Using Reduced LBP, International Journal of Electrical and Computer Engineering, vol. 8, issue 5, pp. 2780-2787, 2018.

[19] Jihad Nader Ismail Shayeb, Ziad Alqadi, Jihad Nader, Analysis of digital voice features extraction methods, International Journal of Educational Research and Development, vol. 1, issue 4, pp. 49-55, 2019.

[20] Ziad Alqadi, Bilal Zahran, Qazem Jaber, Belal Ayyoub, Jamil Al-Azzeh,Enhancing the Capacity of LSB Method by Introducing LSB2Z Method, International Journal of Computer Science and Mobile Computing, vol. 8, issue 3, pp. 76-90, 2019.

[21] Ziad Alqadi, Ahmad Sharadqh, Naseem Asad, Ismail Shayeb, Jamil Al-Azzeh, Belal Ayyoub, A highly secure method of secret message encoding, International Journal of Research in Advanced Engineering andTechnology, vol. 5, issue 3, pp. 82-87, 2019.

[22] Musbah Aqel Ziad A. Alqadi, Performance analysis of parallel matrix multiplication algorithms used in image processing, World Applied Sciences, vol. 6, issue 1, pp. 45-52, 2009.

[23] Jihad Nadir, Ashraf Abu Ein, Ziad Alqadi, A Technique to Encrypt-decrypt Stereo Wave File, International Journal of Computer and Information Technology, vol. 5, issue 5, pp. 465-470, 2016.

[24] Musbah J Aqel, Ziad ALQadi, Ammar Ahmed Abdullah, RGB Color Image Encryption-Decryption Using Image Segmentation and Matrix Multiplication, International Journal of Engineering and Technology, vol. 7, issue 3, pp. 104-107, 2018.

[25] Belal Zahran Rashad J Rasras, Ziad Alqadi, Mutaz Rasmi Abu Sara, B Zahran, Developing new Multilevel security algorithm for data encryption-decryption (MLS_ED), International Journal of Advanced Trends in Computer Science and Engineering, vol. 8, issue 6, pp. 3228-3235, 2019.

[26] Majed O Al-Dwairi, A Hendi, Z AlQadi, An efficient and highly secure technique to encrypt-decrypt color images, Engineering, Technology \& Applied Science Research, vol. 9, issue 3, pp. 4165-4168, 2019.

[27] Amjad Y Hendi, Majed O Dwairi, Ziad A Al-Qadi, Mohamed S Soliman, A novel simple and highly secure method for data encryption-decryption, International Journal of Communication Networks and Information Security, vol. 11, issue 1, pp. 232-238, 2019.

[28] Ziad A AlQadi, Accurate Method for RGB Image
Encryption, International Journal of Computer Science and Mobile Computing, vol. 9, issue 1, pp. 12-21,2020.

[29] Ziad Alqadi, Majid Oraiqat, Hisham Almujafet, Salah Al-Saleh, Hind Al Husban, Soubhi Al-Rimawi, A New Approach for Data Cryptography, International Journal of Computer Science and Mobile Computing, vol. 8, issue 9, pp. 30-48, 2019.

[30] Jamil Al-Azzeh, Ziad Alqadi, Qazem Jaber, A Simple, Accurate and Highly Secure Method to Encrypt-Decrypt Digital Images, JOIV: International Journal on Informatics Visualization, vol. 3, issue 3, pp. 262-265, 2019.

[31] Dr Saleh A Khawatreh Dr Majed, Omar Dwairi, Prof. Ziad Alqadi, Dr. Mohammad S. Khrisat, Dr. Amjad Hindi, Digital color image encryption-decryption using segmentation and reordering, International Journal of Latest Research in Engineering and Technology (IJLRET), vol. 6, issue 5, pp. 6-12, 2020.

[32] Mutaz Rasmi Abu Sara Rashad J. Rasras, Ziad A. AlQadi, A Methodology Based on Steganography and Cryptography to Protect Highly Secure Messages, Engineering, Technology \& Applied Science Research, vol. 9, issue 1, pp. 3681-3684, 2019.

[33] Bilal Zahran, Ziad Alqadi, Jihad Nader, Ashraf Abu Ein, A Comparison BETWEEN PARALLEL AND SEGMENTATION METHODS USED FOR IMAGE ENCRYPTION-DECRYPTION, International Journal of Computer Science \& Information Technology (IJCSIT), vol. 8, issue 5, pp. 125-131, 2016.

[34] PROF. ZIAD A. ALQADI, A SIMPLE METHOD TO ENCRYPT-DECRYPT SPEECH SIGNAL, International Journal of Engineering Technology Research \& Management, vol. 5, issue 2, pp. 44-52, 2021.

[35] Ziad ALQadi, Analysis of stream cipher security algorithm, Journal of Information and Computing Science, vol. 2. Issue 4, pp. 288-298, 2007.

[36] Rashad J Rasras, Mohammed Abuzalata, Ziad Alqadi, Jamil Al-Azzeh, Qazem Jaber, Comparative Analysis of Color Image Encryption-Decryption Methods Based on Matrix Manipulation, International Journal of Computer Science and Mobile Computing, vol. 8, issue 3, pp. 1426, 2019.

[37] Musbah Aqel, Ziad A. Alqadi, Performance analysis of parallel matrix multiplication algorithms used in image processing, World Applied Sciences Journal, vol. 6, issue 1, pp. 45-52, 2009.

[38] Amjad Y Hindi, Majed O Dwairi, Ziad A AlQadi, A Novel Technique for Data Steganography, Engineering, Technology \& Applied Science Research, vol. 9, issue 6, pp. 4942-4945, 2019.

[39] Majed O. Al-Dwairi, Amjad Y. Hendi, Mohamed S. Soliman, Ziad A.A. Alqadi, A new method for voice signal features creation, International Journal of Electrical and Computer Engineering (IJECE), vol. 9, issue 5, pp. 4092-4098, 2019.

[40] Bilal Zahran Belal Ayyoub, Jihad Nader, Ziad Al-Qadi, Suggested Method to Create Color Image Features Victor, Journal of Engineering and Applied Sciences, vol. 14, issue 1, pp. 2203-2207, 2019. 
[41] Akram A Moustafa, Ziad A Alqadi, A Practical Approach of Selectingthe Edge Detector Parameters to Achieve a Good Edge Map of the Gray Image, Journal of Computer Science, vol. 5, issue 5, pp. 355-362, 2009.
[42] Rushdi Abu Zneit, Jamil Al-Azzeh, Ziad Alqadi, Belal Ayyoub, Ahmad Sharadqh, Using Color Image as a Stego-Media to Hide Short Secret Messages, International Journal of Computer Science and Mobile Computing, vol. 8, issue 6, pp. 106-123, 2019. 